\title{
RESEARCH ON CULTIVATION OF TAX RISK CONTROL ABILITY UNDER THE BACKGROUND OF INDUSTRY AND EDUCATION INTEGRATION
}

\author{
Zhu-Ji ${ }^{1}$, Li-Wei Lin ${ }^{*}$ 四 \\ 1 Zhejiang University of Finance and Economics Dongfang College, Zhejiang, China \\ ${ }^{*}$ S School of Information, Zhejiang University of Finance and Economics Dongfang College, Zhejiang, \\ China
}

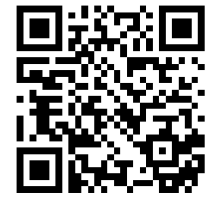

DOI: https://doi.org/10.29121/ijetmr.v8.i2.2021.858

Article Citation: Zhu-Ji, and Li-Wei Lin. (2021). RESEARCH ON CULTIVATION OF TAX RISK CONTROL ABILITY UNDER THE BACKGROUND OF INDUSTRY AND EDUCATION INTEGRATION. International Journal of Engineering Technologies and Management Research, 8(2), 21-28. https://doi.org/10.29121/ijetmr.v8 .i2.2021.858

Published Date: 11 February 2021

\section{Keywords:}

Integration of Production and

Education

Core Competence

Tax Risk Control

Case Teaching

\section{ABSTRACT}

The goal of professional application-oriented construction is to improve students' practical application ability. Under the background of the integration of industry and education, the core ability of taxation major should be highlighted and cultivated is tax risk control ability. Such management ability is increasingly expected by the society among various abilities possessed by professional graduates. The author combined with the professional construction of the working university, from the content design, progress, training experience, optimization and improvement of professional core competence training to explore beneficial, to provide policy optimization suggestions for the cultivation of tax risk management talents.

\section{INTRODUCTION}

\subsection{PROBLEM RAISING AND LITERATURE REVIEW}

\subsubsection{PROBLEM RAISING}

In the reform of higher education, enterprises should play an important role as the main body, promote the comprehensive integration of structural elements of the supply side and industrial demand side of personnel training, and train a large number of high-quality innovative personnel and technical and skilled personnel. Focusing on local application-oriented undergraduate colleges and universities, promoting the integration of industry and education, and school-enterprise cooperation is an effective way to improve the quality of talent training, and a strong guarantee for cultivating qualified talents for local economic development. In zhejiang university of finance and taxation Oriental college undergraduate professional, for example, in the past many years, to train at the collection of public service personnel as the main training goal, but with artificial intelligence, big data, block chain

(C) 2021 The Author(s). This is an open access article distributed under the terms of the Creative Commons Attribution License, which permits unrestricted use, distribution, and reproduction in any medium, provided the original author and source are credited. 
using information technology maturity, and the land tax merger reform cause for employment face Narrows at the same time, fiscal and taxation department of all kinds enterprise sought-after fords the tax service of high quality applied talents. This kind of demand - end market changes, will inevitably cause supply - end chain reaction.

With the continuous improvement of the level of tax collection and management, taxpayers will face greater tax risks and uncertainties, and the ability demands of professionals are also changing significantly, so it is necessary for colleges and universities to make timely changes to realize the Pareto improvement of professional talent training. What kind of tax-related service talent does society need to respond to its expectations? What are the characteristics of the cultivation of taxation major? What are the core abilities of the graduates? In order to answer these questions, this topic research appears to be particularly important, therefore, the author combined with the practice of professional talent training, this issue for special analysis.

\subsubsection{LITERATURE REVIEW}

\section{Overview of views on the integration of industry and education}

There are many researches on the integration of industry and education, and the research content is relatively rich, which lays a good theoretical foundation for the follow-up research.

1) Research on the Problems of "Integration of Industry and Education" in Applied Undergraduates First, the system logic is not straightened out, operability is not strong enough. Song Lei et al. (2020) pointed out that the difficulty of implementing the integration of industry and education and school-enterprise cooperation in colleges and universities is that the form of school-enterprise cooperation is not highly operable. Bai Yixian (2019) pointed out the contradiction between the institutional logic and the development goal of "integration of industry and education", which led to the institutional dilemma of "integration of industry and education". Second, the practical implementation of multi-party support is insufficient. Zhang Guimei, Zhang Ping (2019) et al. 's research pointed out that the existing integration of industry and education, whether for school teachers or enterprises, has insufficient incentives, and the participation of all parties is not high, so it is difficult to form synergy.

2) Research on countermeasures and suggestions to promote the integration of industry and education One is the way to crack the need for multi - force. Du Yunying (2019) pointed out ways to improve teachers' scientific research and service capabilities, improve the evaluation and incentive system, and enhance enterprises' enthusiasm through subsidies and taxation systems. Second, to the policy can form incentive. Song Lei, Yang Zhuoyi and Yu Limin (2020) took the practice of universities in Shandong as an example and proposed that teachers' studios in enterprises and engineers' classrooms in schools are typical modes. Wu Xingmei (2020) proposed continuous improvement of the evaluation system; We will improve the government security system and increase the participation of enterprises.

\section{Study on the Application Construction of Taxation Specialty}

1) Talent training program first

Tian Fa (2018), Ji Li and Tian Fa (2019) take the taxation major of universities in Shanghai as an example to discuss how to optimize the practical teaching system from the aspects of curriculum setting, teaching staff, practice places and evaluation mechanism, etc.It is pointed out that all schools pay more attention to cultivating students' ability of application, practice and innovation. Dong Gentai (2019) took Zhejiang University of Finance and Economics as an example to discuss the orientation of talent training objectives and talent training models for the specialty of taxation. The problems mentioned were universal and the solutions targeted, which could reflect the characteristics of professional training.

2) practical teaching reform

Qiu Qiang (2019) points out that the professional practice teaching reform of taxation should practice teaching goal clear, the optimization of curriculum system, practice off site improvement, applied the teachers troop construction and the evaluation mechanism innovation, etc, to further improve the professional practice teaching content and system, to enhance the level of practice teaching ability, finally realizes the applied talents training goal. Lu Chuncheng (2018) focuses on the construction of tax practice 
teaching, and Li Ya (2018) discusses the reform of experimental teaching of tax science. He Hui and Liu Bin (2017) put forward countermeasures and suggestions for cultivating outstanding talents in tax science.

3) Enhance innovation capability

Chang Xiaosu (2016) discussed the innovative path of professional practice teaching and put forward a reform plan led by classroom, supported by practice, experiment and training, boosted by competition and led by innovative projects.Then, $\mathrm{Wu} \mathrm{Ju}$ and $\mathrm{Wu} \mathrm{Li}$ (2019) proposed to solve the problem through in-depth study of practical courses and innovation of assessment methods, so as to achieve the training goal of innovation ability of tax professionals. Jiang Yuan (2018) proposed the realization path of the integrated development of practical teaching and innovation and entrepreneurship education in the undergraduate specialty of taxation. Xia He (2018) discusses the new ideas of professional graduation thesis reform.

4) Teacher construction and curriculum evaluation

Li Ke (2019), through studying the specialty setting, classroom teaching and teacher management of American colleges and universities, put forward the suggestions of maintaining the continuity of specialty construction, truly realizing the classified management of teacher team, increasing the self-ownership of classroom teaching of teachers, and practically improving the teaching technology. Zhao Zhuoya (2019) pointed out that the construction of training mode should be realized through in-depth investigation, repeated demonstration, accurate positioning of talent training objectives, strengthening the construction of training rooms and practice bases, and vigorously strengthening the construction of teachers.

\section{The literature review}

Existing literature shows that the integration of industry and education is interacting between schools and enterprises. However, due to various reasons such as policies, the original policy objectives have not been fully realized. According to the existing literature, the mode of "integration of production and education" in higher vocational colleges is mature and effective. The practice cycle of application-oriented undergraduate courses is not long enough, so it is difficult to present the effect well, which is also the problem that needs to focus on the in-depth study of individual cases (see Table 1).

Table 1: Taxation undergraduate major part of the university reform research key words statistical

\begin{tabular}{|c|c|c|c|}
\hline $\begin{array}{l}\text { Serial } \\
\text { number }\end{array}$ & Reform of colleges and universities & keywords & Author and Year \\
\hline 1 & $\begin{array}{l}\text { Anhui University of Finance and } \\
\text { Economics }\end{array}$ & $\begin{array}{l}\text { Innovation ability; Teaching mode; } \\
\text { The practice teaching } \\
\text { New economic management, new } \\
\text { finance and economics; } \\
\text { Application-oriented talents }\end{array}$ & $\begin{array}{c}\text { Wu Ju, Wu Li } \\
\text { (2019); Chang } \\
\text { Xiaosu (2016) } \\
\text { Cheng Songbai, } \\
\text { Zhu Feng, Cui } \\
\text { Zhikun (2020) }\end{array}$ \\
\hline 2 & $\begin{array}{l}\text { Zhejiang University of Finance and } \\
\text { Economics }\end{array}$ & $\begin{array}{l}\text { Talent training; Professional } \\
\text { characteristics }\end{array}$ & $\begin{array}{l}\text { Dong Gentai et al. } \\
(2019)\end{array}$ \\
\hline 3 & Six in Shanghai & $\begin{array}{c}\text { Practical teaching system; } \\
\text { Professional Training Program }\end{array}$ & $\begin{array}{l}\text { Tian Fa (2018); } \\
\text { Jili, Tian Fa (2019) }\end{array}$ \\
\hline 4 & $\begin{array}{l}\text { Shandong University of Finance and } \\
\text { Economics }\end{array}$ & $\begin{array}{l}\text { Employment after graduation; The } \\
\text { practice teaching }\end{array}$ & $\begin{array}{c}\text { Lu Chuncheng } \\
\text { (2018) }\end{array}$ \\
\hline 5 & $\begin{array}{l}\text { Dongfang College, Shandong University of } \\
\text { Finance and Economics }\end{array}$ & Training of Professional Talents & Li Keting (2017) \\
\hline 6 & $\begin{array}{l}\text { Xiangsi College, Guangxi University for } \\
\text { Nationalities }\end{array}$ & The experimental teaching & Li Ya（2018） \\
\hline 7 & Hunan College of Commerce & $\begin{array}{l}\text { Teaching staff; The classroom } \\
\text { teaching }\end{array}$ & Li Ke (2019) \\
\hline 8 & $\begin{array}{c}\text { Guangxi University of Finance and } \\
\text { Economics }\end{array}$ & $\begin{array}{c}\text { Innovation; Entrepreneurship; } \\
\text { Professional practice } \\
\text { Training scheme }\end{array}$ & $\begin{array}{c}\text { Jiang Yuan }(2018 \\
\text { (2) }\end{array}$ \\
\hline
\end{tabular}


Research on Cultivation of Tax Risk Control Ability Under the Background of Industry and Education Integration

\begin{tabular}{|c|c|c|c|}
\hline & & & $\begin{array}{c}\text { Ma Nianyi }(2020 \\
\text { ) }\end{array}$ \\
\hline 9 & $\begin{array}{l}\text { Oriental College of Zhejiang University of } \\
\text { Finance and Economics }\end{array}$ & $\begin{array}{l}\text { Practice education; The practice } \\
\text { teaching }\end{array}$ & Zhu Ji（2019） \\
\hline 10 & Guangdong University of Foreign Studies & $\begin{array}{l}\text { Practice teaching base } \\
\text { construction }\end{array}$ & $\begin{array}{l}\text { Wang Zheng, } \\
\text { Deng Jing ( } 2018 \\
\text { ) }\end{array}$ \\
\hline 11 & Liaodong college & Graduation thesis & He Xia（2018） \\
\hline 12 & $\begin{array}{l}\text { Nanjing University of Finance and } \\
\text { Economics, Central University of Finance } \\
\text { and Economics, Shanghai Lixin } \\
\text { Accounting and Finance College }\end{array}$ & Training program; The curriculum & $\begin{array}{l}\text { Li Yonggang（ } \\
\text { 2019） }\end{array}$ \\
\hline 13 & $\begin{array}{c}\text { Capital University of Economics and } \\
\text { Business }\end{array}$ & Training of Excellent Talents & $\begin{array}{l}\text { He Hui, Liu Bin ( } \\
\text { 2017) }\end{array}$ \\
\hline 14 & $\begin{array}{l}\text { Hunan University of Finance and } \\
\text { Economics }\end{array}$ & $\begin{array}{c}\text { Excellent talent training; } \\
\text { Integration of production and } \\
\text { education; Cooperative education }\end{array}$ & $\begin{array}{l}\text { Hu Xiaomei ( } \\
\text { 2020) }\end{array}$ \\
\hline 15 & Shanghai Business School & $\begin{array}{l}\text { Application ability; Evaluation } \\
\text { system of }\end{array}$ & $\begin{array}{l}\text { Yin Shuping, } \\
\text { Yuan Meiqin ( } \\
\text { 2020) }\end{array}$ \\
\hline 16 & $\begin{array}{c}\text { Guizhou University of Finance and } \\
\text { Economics }\end{array}$ & The practice teaching & $\begin{array}{l}\text { Xiao Yuanju ( } \\
\text { 2020) } \\
\end{array}$ \\
\hline 17 & Institute of minjiang & $\begin{array}{l}\text { The practice teaching } \\
\text { Talent training mode }\end{array}$ & $\begin{array}{l}\text { Qiu Qiang } \\
\text { ) } \\
\text { Qiu Qiang, Yin } \\
\text { Lijun (2020) }\end{array}$ \\
\hline
\end{tabular}

Note: According to the China National Knowledge Infrastructure (CNKI) related literature.

In view of the construction of taxation specialty, the information presented by the existing literature is relatively comprehensive and objective, which provides valuable reference experience for the improvement of talent cultivation. The tax major of all universities and colleges actively responds to the application-oriented reform, and can also reform the professional practice teaching system based on their existing resources, and summarize the problems existing in the process of promotion. By comparison, some problems are universal, but the goal of the reform is to serve the cultivation of application-oriented talents in the tax major. The proposed measures and suggestions are targeted to research colleges and universities, and have certain reference significance to the reform and construction of tax science specialty in other colleges and universities.

It is worth noting that most of the existing literature discusses talent training programs from the perspective of practical teaching system, focusing on teaching and not paying enough attention to some non-teaching links. The system construction, evaluation and feedback mechanism of professional talent training is still immature. None of the institutions has a good answer to the question of what the "core competencies" are. Yin Shuping, yuan mei harp (2020) answer the classification of the professional application ability evaluation, focusing on the weighing system discussed, no description analysis combined with the specific colleges, this article will be on the basis of previous research, related institutions professional experience in application of the construction of the taxation, is to learn a tax professional core ability training case. 


\section{PROGRAM DESIGN AND PROMOTION}

\subsection{PROGRAM DESIGN}

To respond to social needs and optimize the design of training programs

Under the background of the integration of industry and education, promoting school-enterprise cooperation is an important measure to improve students' practical application ability.The cultivation of tax-related service talents for enterprises has become the construction direction of taxation major. On the basis of careful investigation, we set up three major directions of tax agent, tax administration and international taxation, and according to the needs of professional ability of each direction, we set up new practical training courses in different modules, or transform the existing theoretical courses with strong theory, so as to give more emphasis to the application of knowledge learning. In the professional practice, we set up a multi-level professional comprehensive training, according to this to meet the urgent needs of students for professional operation skills.

\section{Highlight risk management and control, and refine the contents of tax administration}

In the direction of tax administration, based on the original course of tax administration and in accordance with the business contents of collection, management and inspection, we separate the business contents of tax assessment, set up Tax Administration Practice Training (see Table 2 below), introduce industry tax risk assessment cases, and carry out case practice teaching. At the same time, the course "Tax Inspection" is offered, which combines theory with operation, and carries out professional thinking training from multiple perspectives. Strengthen students' awareness of tax risk control and lay a good foundation for future practice.

Table 2: List of experimental items of Tax Administration Training

\begin{tabular}{|c|c|l|c|}
\hline Serial number & Experimental project & Project type & The experimental class \\
\hline Experimental 1 & System fundamentals and initialization & comprehensive & 3 \\
\hline Experimental 2 & Tax assessment of business super industry & comprehensive & 6 \\
\hline Experimental 3 & Liquor manufacturing industry tax assessment & comprehensive & 9 \\
\hline Experimental 4 & Tax Assessment of Construction Industry (Case 1) & comprehensive & 9 \\
\hline Experimental 5 & Tax Assessment of Construction Industry (Case 2) & comprehensive & 6 \\
\hline Experimental 6 & Tax assessment of road transport industry & comprehensive & 9 \\
\hline Experimental 7 & Tax assessment of tourism industry & comprehensive & 6 \\
\hline Total & & & 48 \\
\hline
\end{tabular}

\section{enhance comprehensive literacy and ability to control tax risks}

According to the program schedule, we will carry out relatively comprehensive practical training at different learning stages in combination with some courses we have learned. With the help of CMAC vocational ability level training test of Caidao website of Taxi You Group, we will carry out the Training Project of Improving Basic Ability of Tax Profession. With the help of the tax hall of the Tax Bureau, the practical project of "Tax Experience and Voluntary Tax Guidance" can significantly enhance students' sense of professional identity, help taxpayers solve tax problems encountered, and effectively improve students' sense of gain. The Comprehensive Analysis of Tax Disputes Cases is carried out on the basis of the case documents published by the court, so as to improve students' ability to cope with tax risks in the future and consciously develop their awareness of tax risk control.

\subsection{CULTIVATION OF TAX RISK CONTROL ABILITY}

\section{Classroom teaching to lay a solid foundation and cultivate tax-related service ability}

Tax risk control ability is the core professional ability, which belongs to the middle training goal in "tax knowledge, tax management and tax saving". The cultivation of management ability is inseparable from solid professional basic business ability and depends on the basic learning of professional courses. Only a solid professional foundation, in order to improve the professional management ability to have a better training. One of the most important courses for the cultivation of tax-related service ability is Tax-related Service Practice, which 
requires a solid foundation of interdisciplinary professional knowledge, which is also the content we pay more attention to in the process of promoting talent cultivation.

\section{Practice link to the case, enhance the tax business risk identification}

In the practice part, the practical training course "Tax Management Practice Training" set up by us conducts classified case analysis according to the industry attributes, training the ability and thinking of tax risk management and control from the aspects of risk index prediction, risk index screening, risk index exclusion, risk index determination, risk index processing and so on.In the course of Tax Inspection, comprehensive cases are also set up to detect tax treatment that does not comply with current laws and regulations, and correct operation (error correction) can be carried out. Continue to train this awareness of risk. In the comprehensive case analysis, using the basic provisions of the tax law, the analysis of the focus of dispute is helpful to understand the risk points in practice, and through the judgment of the court and the judge to predict the risk that may arise in the future, control the tax risk.

\section{Discipline competition promotes training through competition and enhances the ability of tax risk control}

As the environment of tax collection and management has changed greatly, information tax management under big data has made subtle changes in the relationship between the two parties. Both parties of tax collection and collection are consciously controlling tax risks. The tax collection and management side should guard against law enforcement risks and the taxpayers should guard against legal risks of compliance with the tax law.As a professional training of finance and economics universities, it is necessary to train students' ability of tax risk control. In the process of practical teaching, the case evaluation competition of tax risk management and control is organized in the way of "second class", and the discipline competition of case evaluation is adopted to train and cultivate students' ability and awareness of tax risk management and control, to make up for the lack of ability cultivation in the first class teaching, and to promote learning and training through competition.

\section{DEFICIENCIES AND OPTIMIZATION SUGGESTIONS}

\subsection{DEFICIENCIES}

1) To promote the integration of industry and education, enterprises are not deeply involved

In promoting the integration in the process of production and education, the biggest obstacle is that the enterprise participation is not enough, by original culture under the influence of the thinking of tax civil servants, "government, industry, schools, research institutions" cooperation in the process of cultivating applied talents, it is obvious that the government's tax department to participate in more, also formed good cooperation mechanism. The enterprise side sends the force insufficient, the practice link can accept the student practice the number of practice is relatively small. Insufficient participation in the cooperative development of practical courses or the arrangement of practical links, relatively less cooperative achievements and insufficient integration. In the process of cultivating students, there are relatively few opportunities to perceive practical tax risks, which is not conducive to cultivating the ability of tax management business.

2) The cultivation of tax risk control ability is modularized, and the feedback of practice test is not timely

The requirement of labor market for tax-related service personnel is no longer satisfied with the traditional bookkeeping and tax declaration business, but can comprehensively control the tax risk that enterprises may face from the perspective of enterprises. Modular cultivation of this kind of ability can be completed in school, but it is not enough to test this kind of cultivation effect only by simulation training and examination in school. It needs to be tested in practice. At present, the first class of graduates after the program reform has not graduated, it is difficult to test the effect of talent training. 
3) The matching degree of other special knowledge, ability and accomplishment cultivation is not high, which affects the cultivation effect

For a qualified tax-related service personnel, there are corresponding requirements for knowledge, ability and accomplishment, and the cultivation of professional core competence depends on other professional and nonprofessional knowledge, ability and accomplishment. For the current training orientation, students need to master not only professional knowledge, other aspects of the ability and quality, and it is difficult to be reflected in a professional education, the foundation is not solid, will affect the future tax related business processing.

\subsection{OPTIMIZATION SUGGESTIONS}

1) Expand the cooperation with more tax agent firms, and deeply participate in professional personnel training

18 professional existing external cooperation unit, of which only three tax accountant point, and the distribution in the provincial capital city (not in the school is located), suggest the stationing, according to the prefecture level choose one key in-depth cooperation, such as the fords the tax service practice course outsource tax accountant to complete such a practice, draw lessons from some of the professional practice of law, and the guidance of graduation thesis reply, invite taxation cadres and tax, and strengthen the communication with practice and communication, make social forces to participate in professional personnel training, refining the integration of production and education professional training characteristics, service personnel training.

2) Subject competitions should encourage more students to participate in the "second class"

In order to make up for the deficiency of the practice part and professional practice link of the first class, the professional discipline competition is promoted in the second class. Tax law knowledge competition strengthens professional foundation, tax skills competition trains business operation, case evaluation competition trains professional thinking of risk management, cultivates professional core ability, and internalizes the concept and thinking of risk management in heart. Competitive training is more conducive to the cultivation of professional core ability, forming a good atmosphere for the whole training process.

3) There should be a more scientific and reasonable evaluation system for professional personnel training

According to the teaching goal theory of Trump, the more advanced the goal is, the more difficult it is to evaluate the progressive goal of knowledge, application and innovation. For in the tax administration practice, case, and data on a given financial system have given reference answer, the student is easy to learn, but in the future practice, the problems will be more complex, whether can effectively cope with, and creative to solve the new problems facing the, was to see a way of professional core ability training effect.Suggested by "government tax department - tax agency - financial institutions - tax research organization expert group of related professionals to develop professional talents cultivation industry standards, professional core ability training will be written into the industry standard, and give a higher proportion, embody the features of talent cultivation, enhance the quality of personnel training.

\section{SOURCES OF FUNDING}

This research received no specific grant from any funding agency in the public, commercial, or not-for-profit sectors.

\section{CONFLICT OF INTEREST}

The author have declared that no competing interests exist.

\section{ACKNOWLEDGMENT}

This research was supported by the Zhejiang University of Finance and Economics Dongfang College , under contract Higher Education Research Project of Zhejiang Province Association for Higher Education in 2020（NO : KT2020352). 


\section{REFERENCES}

[1] Wu Xingmei. Reflections on the Cultivation Mode of Integrating Industry and Education in Applicationoriented Universities [J]. Journal of Jilin Agricultural Science and Technology University,2020, 29(01):94-98.

[2] Song Lei, Yang Zhuoyi, Yu Limin. Research on the current situation and countermeasures of implementing industry-teaching integration and school-enterprise cooperation in application-oriented universities [J]. Education and Teaching Forum,2020(12):63-64.

[3] Du Yunying. Dilemma and Breakdown of the Integration of Industry and Education in Local Undergraduate Universities [J]. University (Research Edition),2019(01):21-27+10.

[4] Bai Yixian. Development Dilemma of "Industry and Education Integration" Organization in High-level Colleges with Industry Characteristics -- Based on Multiple Institutional Logic Analysis [J]. China Higher Education Research,2019(04):86-91.

[5] Zhang Guimei, Zhang Ping. College Talent Training and the Integration of Industry and Education 2.0 Era [J]. Heilongjiang Education (Theory and Practice),2019(11): 25-27.

[6] Wu Ju, Wu Li. Research on Teaching Mode of Cultivating Innovative Ability of Tax Professionals from the Perspective of "Internet $+"$ [J]. Journal of Heilongjiang Institute of Technology (General Edition),2019,19(01):15-21.

[7] Lu Chuncheng, Wu Jiameng. Research on Practical Ability Cultivation of College Students' Employment: A Case Study of Taxation Major in Shandong University of Finance and Economics [J]. China's Collective Economy,2018(10):163-164.

[8] Li Ya. Research and Practice on Experimental Teaching of Taxation Major in Independent Colleges -- A Case Study of Xiangsihu College, Guangxi University for Nationalities [J]. Rural Economy and Science \& Technology,2019,30(17):328-329.

[9] Li ke. Inspiration from the Specialty Setting and Classroom Teaching of American Universities to the Specialty Construction of Chinese Local Universities -- Based on Finance and Taxation Specialty [J]. Science and Education Guide (Late Edition),2019(01):6-7.

[10] Ji Li, Tian Fa. Comparative Analysis of the Cultivation Program of Taxation Major in Shanghai Undergraduate Universities [J]. Journal of Higher Education,2019(12): 153-154 + 158.

[11] Jiang Yuan. Analysis on the Integration Development Path of Practical Teaching and Innovation and Entrepreneurship Education for Undergraduate Taxation [J]. Chinese and foreign entrepreneurs, 2018(20): 159-160.

[12] Dong Gentai, Shen Yuping, Si Yanwu. Thinking and exploration on the reform of talent training mode for tax science [J]. Journal of Jilin Radio and TV University,2019(01):108-110.

[13] Journal of Hubei Correspondence University,2017,30(01):99-101. He Hui, Liu Bin. Research on Training Model of Outstanding Talents in Tax Science [J]. Journal of Hubei Correspondence University,2017,30(01):99101.

[14] Zhao Zhuoya. Research on the Cultivation Model of Tax Professionals in New-established Undergraduate Universities [J]. Journal of Henan Institute of Education (Philosophy and Social Sciences Edition), 2019,38(03):53-57.

[15] He Xia. Problems and Countermeasures of Graduation Thesis of Taxation Major in Applied Undergraduate Colleges -- A Case Study of Liaodong University [J]. Journal of Science, 2018(35):11-12.

[16] QIU Qiang. Research on Practical Teaching Reform of Taxation Major in Application-oriented Undergraduate Colleges [J]. Journal of Xuchang University,2019,38(06):143-147.

[17] Yin Shuping, Yuan Meiqin. Construction of Application Ability Evaluation System for Students majoring in Taxation -- Based on the Research of Application-oriented Universities [J]. Journal of Hebei University of Economics and Business (Comprehensive Edition),2020(04):89-91. 